\title{
Antibiotics Treatment and Immune-checkpoint Inhibitors Efficacy: A Systematic Review and Meta-analysis
}

Jie Hao

Third Military Medical University Southwest Hospital

Yang Zhao

Third Military Medical University Southwest Hospital

Jiangyi He

Third Military Medical University Southwest Hospital

Yunlong Wang

Third Military Medical University Southwest Hospital

Yan Dong ( $\sim$ dongyan028@sina.com )

Third Military Medical University Southwest Hospital

\section{Research}

Keywords: antibiotics, immune-checkpoint inhibitors, cancer, prognosis, meta-analysis

Posted Date: May 29th, 2020

DOI: https://doi.org/10.21203/rs.3.rs-30778/v1

License: (c) (i) This work is licensed under a Creative Commons Attribution 4.0 International License. Read Full License 


\section{Abstract}

Background: Immune-checkpoint inhibitors (ICls) have been approved as 1st line therapy and benefit patients with advanced cancer. However, still many patients fail to achieve the significant efficacy, a predictor for precise patient selection is needed. The aim of our study is to determine whether the administration of antibiotics before or at the beginning of ICls treatment is a prognostic factor of progression-free survival (PFS) and overall survival (OS) in patients with advanced cancer.

Methods: A systematic search in PubMed, Embase, Cochrane and Web of Science databases was conducted using the search terms antibiotic, PD-1, PD-L1, CTLA-4, combined with cancer, tumor, neoplasm, or carcinoma. Data extraction was performed independently. Hazard ratio (HR) for PFS and OS of antibiotics (+) group vs antibiotics (-) group were pooled according to random or fixed-effects models. HRs with $95 \%$ confidence intervals (Cls) for PFS and OS were pooled to obtain prognostic information and aggregate values.

Results: Nine studies including 1163 patients were included in this meta-analysis. By PFS analysis, antibiotics administration was associated with a significantly increased risk of disease progression $(\mathrm{HR}, 1.76 ; 95 \% \mathrm{Cl}, 1.37-2.26 ; P<$ 0.01). By OS analysis, antibiotics uptake also showed an $\mathrm{HR}$ in favor of death $(\mathrm{HR}, 1.7 ; 95 \% \mathrm{Cl}, 1.40-2.07 ; P<0.01)$.

Conclusions: Based on the existing evidence, antibiotics administration is a prognostic factor for reduced PFS and OS in patients receiving ICls treatment. The time interval between antibiotics administration and ICls treatment should be considered.

\section{Background}

Cancer immunotherapy has become highly successful against an array of distinct hematological and solid metastatic malignancies. Administration of ICls unleashes T lymphocyte-mediated immune responses by targeting the inhibitory signals, Programmed cell death (PD)-1, Programmed cell death ligand (PDL)-1 and Cytotoxic T-lymphocyte associated protein (CTLA)-4. However, despite these multiple ICls were utilized in cancer treatment, overall survival in patients remains heterogeneous[1, 2]. Predictor is a good indicator of the efficacy of immunotherapy, but the current relevant researches are extremely limited, and results regarding the best-studied marker PD-L1 is not yet ideal[3]. Therefore, an improved understanding of factors associated with clinical outcomes of ICls could optimize personalized treatment and provide new insights into resistance mechanisms.

The microbiota is an extremely important and complex ecosystem that continuously interacts with and regulates its host's immune system. Early in life, the developing gut microbiota helps train and shape the immature immune system, and improper immune responses or poor prognosis later in life are often associated with an altered gut microbiota. The balance of microbiome needed for immune homeostasis could be influenced by factors such host genetics, lifestyle and exposure to antibiotics treatment. Given the widespread use of antibiotics in clinical settings, attention has been recently drawn upon the association between antibiotics use and immunotherapy efficacy. Previous studies, predominantly in mice, consistently indicated that the dysbiosis of microbiota by antibiotics impacts individual's response to cyclophosphamide, platinum agents and immunotherapies, such as anti-PD-1, anti-PD-L1 or anti-CTLA-4 antibodies[4-7], but substantive data in humans are scarce. Now that the results of several cohort trials with ICls have become available, we performed a systematic review and meta-analysis to determine whether the effectiveness of ICls was affected by antibiotics use or not in the duration of treatment.

\section{Materials And Methods}

- Literature Search 
This systematic review and meta-analysis was performed according to the Preferred Reporting Items for Systematic Reviews and Meta-Analyses (PRISMA) statement and the Cochrane Handbook for Systematic Reviews of Interventions. We systematically searched PubMed, Embase, the Cochrane Library, and Web of Science to identify studies published from inception to July 2019 that examined the association of antibiotics use with the prognosis of patients undergoing ICls treatment for advanced cancer. The bibliographic search was performed by Yang Zhao and Yunlong Wang in July 2019. The following search terms were used: "cancer or tumor or neoplasm or carcinoma" and "antibiotic" and "PD-1 or PD-L1 or CTLA-4". Outcomes of interest included PFS and OS.

\section{- Study Selection and Data Extraction}

Studies that fulfilled the following criteria were included: (1) antibiotics usage was reported among variables of survival analysis, (2) survival information (progression-free survival [PFS] or overall survival [OS]) was available, (3) articles were published in English. If studies with overlapping participants were encountered, the reports with the larger sample size were included in the present meta-analysis. Abstracts, reviews, letters to the editor, and investigations with designs other than a cohort study were excluded.

Two authors (Jie Hao and Yang Zhao) conducted the search and identification independently, and the selection of an article was reached by consensus with a third author (Jiangyi He). The following information was extracted from each report by the 2 authors independently: author, year of publication, country, tumor type, patient number, time of antibiotic treatment, median PFS and OS, and survival data ( $\mathrm{HRs}, 95 \% \mathrm{Cls}$ ) of antibiotics (+) group vs antibiotics (-) group. If the necessary data were provided in a graph of the study, Engauge Digitizer version 4.1 (http://digitizer.sourceforge.net/) was employed to extract the corresponding data. Otherwise, the corresponding author of the published study was contacted to obtain the data required for the analysis.

\section{Statistical Analysis}

Data of HRs and the lower and upper limits of their $95 \% \mathrm{Cls}$ were extracted to calculate log HRs and their corresponding SEs. The logarithmically transformed SIRs and their corresponding SEs were used to stabilize the variance and normalize the distribution. The Cochran $\mathrm{Q}$ test and the $\mathrm{I}^{2}$ statistic were used to evaluate the heterogeneity among the included cohort studies, $P<0.05$ or $\mathrm{I}^{2}>50 \%$ was defined as heterogeneity, and the random-effects model would be used. Potential publication bias was assessed by funnel plots with the Egger regression asymmetry test. Sensitivity analysis was performed to assess the influence of each individual dataset on overall results. RevMan, version 5.3 (Cochrane Collaboration) was used for the statistical analyses. $P<0.05$ was considered significant.

\section{Results}

The literature searching process and study identification were summarized in Fig. 1. In brief, for the 1635 records that were initially identified from the database searching, and 16 were further screened for full-text review. For the 16 records, 2 reported the risk ratio, 3 did not included patient cohort, 2 were overlapped with the smaller sample size, and 9 were finally identified for systematic review and meta-analysis[8-16]. Overall, the total number of patients included was 1163 ranging from 42 to 239 per tumor type of study, and 999 (85.9\%) were prescribed antibiotics mostly within 2 months before or 1 month after the first administration of PD-1/PD-L1/CTLA-4 mAb, which represented non-small cell lung cancer (NSCLC), renal cell carcinoma (RCC), urothelial carcinoma (UC), and melanoma (MELAN). Among patients with NSCLC, some participants were overlapped in 3 studies respectively[12, 17, 18], the larger sample size and the most informative one was selected[12]. The major characteristics were shown in Table 1. 
Table 1

Characteristics of the Included Studies Comparing Antibiotics (+) With Antibiotics (-).

\begin{tabular}{|c|c|c|c|c|c|c|c|}
\hline $\begin{array}{l}\text { Author, } \\
\text { year }\end{array}$ & Country & $\begin{array}{l}\text { Tumor } \\
\text { type }\end{array}$ & Participants & $\begin{array}{l}\text { ATB(+)/ATB(-) } \\
\text { number }\end{array}$ & $\begin{array}{l}\text { Use time } \\
\text { of } \\
\text { antibiotic }\end{array}$ & $\begin{array}{l}\text { ATB(+)/ATB(-) } \\
\text { median PFS }\end{array}$ & $\begin{array}{l}\text { ATB }(+) / A T B(-) \\
\text { median OS }\end{array}$ \\
\hline $\begin{array}{l}\text { Ahmed et } \\
\text { al, } \\
2018\end{array}$ & America & $\begin{array}{l}\text { Advanced } \\
\text { cancer }\end{array}$ & 60 & 17 vs 43 & $\begin{array}{l}-0.5 \sim+ \\
0.5\end{array}$ & NA & 5.6 vs 20.8 \\
\hline $\begin{array}{l}\text { Derosa et } \\
\text { al, } \\
2018\end{array}$ & France & $\begin{array}{l}\text { Non-small } \\
\text { cell lung } \\
\text { cancer }\end{array}$ & 239 & 48 vs 191 & $-2 \sim 0$ & 1.9 vs 3.8 & 7.9 vs 24.6 \\
\hline $\begin{array}{l}\text { Derosa et } \\
\text { al, } \\
2018\end{array}$ & France & $\begin{array}{l}\text { Renal cell } \\
\text { carcinoma }\end{array}$ & 121 & 16 vs 105 & $-2 \sim 0$ & 1.9 vs 7.4 & 17.3 vs 30.6 \\
\hline $\begin{array}{l}\text { Routy et } \\
\text { al, } \\
2018\end{array}$ & France & $\begin{array}{l}\text { Urothelial } \\
\text { carcinoma }\end{array}$ & 42 & 12 vs 30 & $-2 \sim+1$ & 1.8 vs 4.3 & 11.5 vs NA \\
\hline $\begin{array}{l}\text { Routy et } \\
\text { al, } \\
2018\end{array}$ & France & $\begin{array}{l}\text { Non-small } \\
\text { cell lung } \\
\text { cancer }\end{array}$ & 140 & 37 vs 103 & $-2 \sim+1$ & 3.5 vs 2.8 & 8.3 vs 15.3 \\
\hline $\begin{array}{l}\text { Huemer et } \\
\text { al, } \\
2019\end{array}$ & Austria & $\begin{array}{l}\text { Non-small } \\
\text { cell lung } \\
\text { cancer }\end{array}$ & 142 & 62 vs 80 & $-1 \sim+1$ & 3.8 vs 4.0 & 14.6 vs 11.2 \\
\hline $\begin{array}{l}\text { Kaderbhai } \\
\text { et al, } \\
2017\end{array}$ & France & $\begin{array}{l}\text { Non-small } \\
\text { cell lung } \\
\text { cancer }\end{array}$ & 74 & 15 vs 59 & $-3 \sim$ & NA & NA \\
\hline $\begin{array}{l}\text { Hakozaki } \\
\text { et al, } \\
2019\end{array}$ & Japan & $\begin{array}{l}\text { Non-small } \\
\text { cell lung } \\
\text { cancer }\end{array}$ & 90 & 13 vs 77 & $-4 \sim 0$ & 1.2 vs 4.4 & 8.8 vs NR \\
\hline $\begin{array}{l}\text { Elkrief et } \\
\text { al, } \\
2019\end{array}$ & Canada & Melanoma & 74 & 10 vs 64 & $-1 \sim 0$ & 2.4 vs 7.3 & 10.7 vs 18.3 \\
\hline $\begin{array}{l}\text { Zhao et } \\
\text { al, } \\
2019\end{array}$ & China & $\begin{array}{l}\text { Non-small } \\
\text { cell lung } \\
\text { cancer }\end{array}$ & 109 & 20 vs 89 & $-1 \sim+1$ & 3.7 vs 9.6 & 6.1 vs 21.9 \\
\hline $\begin{array}{l}\text { Krief et al, } \\
2019\end{array}$ & France & $\begin{array}{l}\text { Non-small } \\
\text { cell lung } \\
\text { cancer }\end{array}$ & 72 & 30 vs 42 & $-2 \sim+1$ & 2.8 vs 3.3 & 5.1 vs 13.4 \\
\hline
\end{tabular}

Forest plot analyses of outcomes from traditional random or fixed effects meta-analyses comparing antibiotics $(+)$ group with antibiotics (-) group ICls patients were shown in Fig. 2 and Fig. 3. For PFS analysis, 8 studies with at least 4 tumor types were included, a pooled HR of 1.76 (Random; $95 \% \mathrm{Cl}, 1.37-2.26 ; P<0.01$ ) from analysis suggested that patients under ICls treatment with antibiotics administration had an inferior PFS compared with those without antibiotics use, 
with moderate heterogeneity $\left(I^{2}=53 \%, P_{h}=0.02\right)$. Subgroup analyses based on the type of tumors showed that the association between antibiotics use and PFS was moderately weakened in non-small cell lung cancer compared to the other cancers (HR 1.54, 95\% Cl 1.16-2.04, Fig. 4). Furthermore, based on the statistical methods, subgroup analyses resulted in significant heterogeneity between subgroups (subgroup difference $P \otimes 0.01,1^{2}=89.2 \%$ ) and non-significant differences in subgroups (Multivariate analysis: HR 2.52, 95\% $\mathrm{Cl} 1.84-3.46, \mathrm{I}^{2}=0 \%, P_{h}=0.42$; Non-multivariate analysis: HR 1.39, 95\% Cl 1.11-1.72, $\mathrm{I}^{2}=22 \%, P_{h}=0.28$, respectively, Fig. 5). For OS analysis, the pooled HR also indicated the shorter survival time for ICls patients with antibiotics treatment (Fixed; HR 1.70, 95\% Cl 1.40-2.07, $\mathrm{I}^{2}=28 \%, P=0.17$, Fig. 3).

The publication bias of PFS and OS was determined (Fig. 6). The shape of funnel plots showed a slight asymmetry, and the power of the test was insufficient for the limited studies. We also conducted Begg's and Egger's test for the 2 effect sizes mentioned above, the results demonstrated that PFS may have potential bias $(P<0.05)$, and no obvious bias was indicated for OS $(P \otimes 0.05)$. Sensitivity analyses did not indicate alterations in the results due to the inclusion of any individual study (Fig. 7), that is, no single study affected the pooled HR.

\section{Discussion}

Advanced cancer treatment was dominated by chemotherapy and radiotherapy, the progress in target therapy and immunotherapy has greatly improved the outcome of cancer patients, especially the administration of ICls benefits many of them[19]. However, part patients treated with ICls still failed to achieve significant efficacy and prolonged PFS.

Although there are reported that the expression level of PD-L1, tumor mutation burden, infiltrate lymphocytes could partly predict the efficacy of ICls treatment[20-22], finding out more precise predictive factor is essential to improve the immunotherapy.

The microbiota is a relatively fragile but extremely important ecosystem influencing host immunity[23]. The microbiota loses homeostasis in a constitutive manner is closely related to tumor progression, raising the question of whether antibiotics changing the composition of microbiota affects immunologic processes, especially its immunotherapy. In recent years, there has been an upsurge of interest in gut microbiota due to its regulatory potential for the immunotherapy of cancers. It was first evaluated in murine models and preclinical studies showed the contribution of gut microbiome in the efficacy of ICls. Civan et al. demonstrated that tumor progression of melanoma in mice harboring distinct Bifidobacterium was nearly abolished with anti-PD-L1 combination treatment. Augmented dendritic cell function leading to enhanced CD8 + T cells priming and accumulation in the tumor microenvironment mediated the effect[5]. Similarly, tumor growth of sarcomas in mice housed in specific pathogen-free condition was inhibited by anti-CTLA-4 in contrast to mice housed in germ-free condition, and the activation of splenic lymphocytes and tumor-infiltrating lymphocytes mediated by anti-CTLA-4 could be significantly decreased in germ-free and antibiotic-treated mice[6]. In addition, the higher alpha diversity and relative abundance of Ruminococcaceae bacteria in melanoma patients was confirmed to be associated with enhancing systemic and anti-tumor immunity[24].The important role of microbiota in tumors makes them interesting forecast indicators for the immunotherapy.

Antibiotics are recognized to be able to shift the microbiota composition, decrease the microbiota diversity and impact on taxonomic richness, which returns to its baseline within 1-3 months or even longer after antibiotics discontinuation[25,26]. Moreover, according to the statistics in 2010, the estimated global consumption of antibiotics was 70 billion individual doses, and the annual rates continue to grow steadily[27]. Given this widespread use of antibiotics, their potential effects on gut microbiota-associated immunotherapy and links with prognostic outcomes has substantial implications for public health. In the present study, our analyses of large and independent cohorts of patients with advanced cancer treated with contemporary ICls showed that antibiotics administration was associated with both 
reduced PFS and OS in patients receiving ICls treatment. In addition, the data indicated that the difference between patients with and without antibiotics use in PFS was more significant than OS, although a moderate heterogeneity was presented in PFS $\left(I^{2}=53 \% ; P=0.02\right)$. Regarding the differences in inclusion criteria of various researches, such as tumor types, statistical methods, broader intervention time of antibiotic medication[11, 13], and polycentric source[12], the heterogeneity for PFS was reasonable.

Our study has some limitations that should be considered when interpreting the results. As inherent in other meta analyses of observational studies, we could not exclude the possibility that some residual factors may confound the association between antibiotics and immunotherapy efficacy, such as the categories, doses, and duration of antibiotics, because we did not have access to individual patient data of the included cohorts. Also, factors such as age at onset of treatment, or gender may potentially affect the association between antibiotics and immunotherapy efficacy, these factors were generally not reported in the original studies, so they could not be analyzed accordingly in the metaanalysis. In addition, we did not include studies in other databases, not written in English, or published as a conference abstract. However, including literature reports from PubMed, EMBASE, Web of Science, and the Cochrane Library published only in English should have covered the majority of the cases. Finally, the main tumor types were focused on lung and urinary system included in the meta-analysis, more types and larger sample size are needed to determine the association between antibiotics and immunotherapy efficacy.

\section{Conclusions}

The results of this meta-analysis demonstrated that antibiotics use during immunotherapy is a prognostic factor for an increasing risk of disease progression compared with the general population. Given the widespread use of antibiotics in clinical settings, harmful aspect may be noted especially for patients with immunotherapy. Reasonable time of maintaining antibiotic treatment efficacy while minimizing its impact on immunotherapy should be well considered.

\section{Declarations}

\section{Ethics approval and consent to participate}

Not applicable' for that section.

\section{Consent for publication}

Written informed consent for publication was obtained from all participants.

\section{Availability of data and materials}

All data, models, and code generated or used during the study appear in the submitted article.

\section{Competing interests}

The authors declare no conflict of interests.

\section{Funding}


This research was funded by the Foundation Research Project of Third Military Medical University affiliated Southwest Hospital, grant number SWH2017YBXM-28 and the National Natural Science Foundation of China, grant number 81803028.

\section{Author Contributions}

Concept and Design, Hao Jie; Collection and assembly of data, Zhao Yang, Wang Yunlong and He Jiangyi; Data analysis and interpretation, Zhao Yang and Hao Jie; Manuscript writing, all authors; Final approval of manuscript, all authors.

\section{List Of Abbreviations}

Progression-free survival [PFS] ,Overall survival [OS],Immune-checkpoint inhibitors (ICls), Programmed cell death[PD],Programmed cell death ligand [PDL],Cytotoxic T-lymphocyte associated protein [CTLA],Systematic Reviews and Meta-Analyses [PRISMA], Hazard ratio [HR],Confidence intervals [CIs], Standard Error[SE],Standardized incidence ratio $[S I R]$.

\section{References}

1. 1 Motzer RJ, Escudier B, McDermott DF, George S, Hammers HJ, Srinivas S, et al. Nivolumab versus Everolimus in Advanced Renal-Cell Carcinoma. N Engl J Med (2015) 373:1803-13. doi: 10.1056/NEJMoa1510665.

2. 2 Borghaei H, Paz-Ares L, Horn L, Spigel DR, Steins M, Ready NE, et al. Nivolumab versus Docetaxel in Advanced Nonsquamous Non-Small-Cell Lung Cancer. N Engl J Med (2015) 373:1627-39. doi: 10.1056/NEJMoa1507643.

3. 3 Zerdes I, Matikas A, Bergh J, Rassidakis GZ, and Foukakis T. Genetic, transcriptional and post-translational regulation of the programmed death protein ligand 1 in cancer: biology and clinical correlations. Oncogene (2018) 37:4639-4661. doi: 10.1038/s41388-018-0303-3.

4. 4 Geller LT, Barzily-Rokni M, Danino T, Jonas OH, Shental N, Nejman D, et al. Potential role of intratumor bacteria in mediating tumor resistance to the chemotherapeutic drug gemcitabine. Science (2017) 357:1156-1160. doi: 10.1126/science.aah5043.

5. 5 Sivan A, Corrales L, Hubert N, Williams J B, Aquino-Michaels K, Earley ZM, et al. Commensal Bifidobacterium promotes antitumor immunity and facilitates anti-PD-L1 efficacy. Science (2015) 350:1084-9. doi: $10.1126 /$ science.aac4255.

6. 6 Vetizou M, Pitt JM, Daillere R, Lepage P, Waldschmitt N, Flament C, et al. Anticancer immunotherapy by CTLA4 blockade relies on the gut microbiota. Science (2015) 350:1079-84. doi: 10.1126/science.aad1329.

7. 7 Viaud S, Saccheri F, Mignot G, Yamazaki T, Daillere R, Hannani D, et al. The intestinal microbiota modulates the anticancer immune effects of cyclophosphamide. Science (2013) 342:971-6. doi: 10.1126/science.1240537.

8. 8 Ahmed J, Kumar A, Parikh K, Anwar A, Knoll BM, Puccio C, et al. Use of broad-spectrum antibiotics impacts outcome in patients treated with immune checkpoint inhibitors. Oncoimmunology (2018) 7:e1507670. doi: $10.1080 / 2162402 X .2018 .1507670$.

9. 9 Derosa L, Hellmann MD, Spaziano M, Halpenny D, Fidelle M, Rizvi H, et al. Negative association of antibiotics on clinical activity of immune checkpoint inhibitors in patients with advanced renal cell and non-small-cell lung cancer. Ann Oncol (2018) 29:1437-1444. doi: 10.1093/annonc/mdy103.

10. 10 Elkrief A, El Raichani L, Richard C, Messaoudene M, Belkaid W, Malo J, et al. Antibiotics are associated with decreased progression-free survival of advanced melanoma patients treated with immune checkpoint inhibitors. Oncoimmunology (2019) 8:e1568812. doi: 10.1080/2162402X.2019.1568812. 
11. 11 Hakozaki T, Okuma Y, Omori M, and Hosomi Y. Impact of prior antibiotic use on the efficacy of nivolumab for non-small cell lung cancer. Oncol Lett (2019) 17:2946-2952. doi: 10.3892/ol.2019.9899.

12. 12 Huemer F, Lang D, Westphal T, Gampenrieder SP, Hutarew G, Weiss L, et al. Baseline Absolute Lymphocyte Count and ECOG Performance Score Are Associated with Survival in Advanced Non-Small Cell Lung Cancer Undergoing PD-1/PD-L1 Blockade. J Clin Med (2019) 8. doi: 10.3390/jcm8071014.

13. 13 Kaderbhai C, Richard C, Fumet JD, Aarnink A, Foucher P, Coudert B, et al. Antibiotic Use Does Not Appear to Influence Response to Nivolumab. Anticancer Res (2017) 37:3195-3200. doi: 10.21873/anticanres.11680.

14. 14 Ouaknine Krief J, Helly de Tauriers P, Dumenil C, Neveux N, Dumoulin J, Giraud V, et al. Role of antibiotic use, plasma citrulline and blood microbiome in advanced non-small cell lung cancer patients treated with nivolumab. J Immunother Cancer (2019) 7:176. doi: 10.1186/s40425-019-0658-1.

15. 15 Routy B, Le Chatelier E, Derosa L, Duong CPM, Alou MT, Daillere R, et al. Gut microbiome influences efficacy of PD-1-based immunotherapy against epithelial tumors. Science (2018) 359:91-97. doi: 10.1126/science.aan3706.

16. 16 Zhao S, Gao G, Li W, Li X, Zhao C, Jiang T, et al. Antibiotics are associated with attenuated efficacy of anti-PD1/PD-L1 therapies in Chinese patients with advanced non-small cell lung cancer. Lung Cancer (2019) 130:10-17. doi: 10.1016/j.lungcan.2019.01.017.

17. 17 Huemer F, Rinnerthaler G, Lang D, Hackl H, Lamprecht B, and Greil R. Association between antibiotics use and outcome in patients with NSCLC treated with immunotherapeutics. Ann Oncol (2019) 30:652-653. doi: 10.1093/annonc/mdz021.

18. 18 Huemer F, Rinnerthaler G, Westphal T, Hackl H, Hutarew G, Gampenrieder SP, et al. Impact of antibiotic treatment on immune-checkpoint blockade efficacy in advanced non-squamous non-small cell lung cancer. Oncotarget (2018) 9:16512-16520. doi: 10.18632/oncotarget.24751.

19. 19 Constantinidou A, Alifieris C and Trafalis DT. Targeting Programmed Cell Death -1 (PD-1) and Ligand (PD-L1): A new era in cancer active immunotherapy. Pharmacol Ther (2019) 194:84-106. doi:

10.1016/j.pharmthera.2018.09.008.

20. 20 Wang F, Wei XL, Wang FH, Xu N, Shen L, Dai GH, et al. Safety, efficacy and tumor mutational burden as a biomarker of overall survival benefit in chemo-refractory gastric cancer treated with toripalimab, a PD1 antibody in phase lb/II clinical trial NCT02915432. Ann Oncol (2019). doi: 10.1093/annonc/mdz197.

21. 21 Ghate K, Amir E, Kuksis M, Hernandez-Barajas D, Rodriguez-Romo L, Booth CM, et al. PD-L1 expression and clinical outcomes in patients with advanced urothelial carcinoma treated with checkpoint inhibitors: A metaanalysis. Cancer Treat Rev (2019) 76:51-56. doi: 10.1016/j.ctrv.2019.05.002.

22. 22 Morrison C, Pabla S, Conroy JM, Nesline MK, Glenn ST, Dressman D, et al. Predicting response to checkpoint inhibitors in melanoma beyond PD-L1 and mutational burden. J Immunother Cancer (2018) 6:32. doi: 10.1186/s40425-018-0344-8.

23. 23 lida N, Dzutsev A, Stewart C A, Smith L, Bouladoux N, Weingarten RA, et al. Commensal bacteria control cancer response to therapy by modulating the tumor microenvironment. Science (2013) 342:967-70. doi: 10.1126/science.1240527.

24. 24 Gopalakrishnan V, Spencer CN, Nezi L, Reuben A, Andrews MC, Karpinets TV, et al. Gut microbiome modulates response to anti-PD-1 immunotherapy in melanoma patients. Science (2018) 359:97-103. doi: 10.1126/science.aan4236.

25. 25 Palleja A, Mikkelsen KH, Forslund SK, Kashani A, Allin KH, Nielsen T, et al. Recovery of gut microbiota of healthy adults following antibiotic exposure. Nat Microbiol (2018) 3:1255-1265. doi: 10.1038/s41564-018-0257-9.

26. 26 Suez J, Zmora N, Zilberman-Schapira G, Mor U, Dori-Bachash M, Bashiardes S, et al. Post-Antibiotic Gut Mucosal Microbiome Reconstitution Is Impaired by Probiotics and Improved by Autologous FMT. Cell (2018) 
174:1406-1423 e16. doi: 10.1016/j.cell.2018.08.047.

27. 27 Van Boeckel TP, Gandra S, Ashok A, Caudron Q, Grenfell BT, Levin SA, et al. Global antibiotic consumption 2000 to 2010: an analysis of national pharmaceutical sales data. Lancet Infect Dis (2014) 14:742-750. doi:

10.1016/S1473-3099(14)70780-7.

\section{Figures}

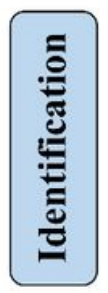

\section{Studies identified by database search $(n=1635)$}

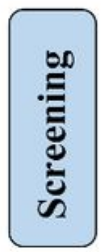

Studies after duplicates removed $(\mathrm{n}=1056)$

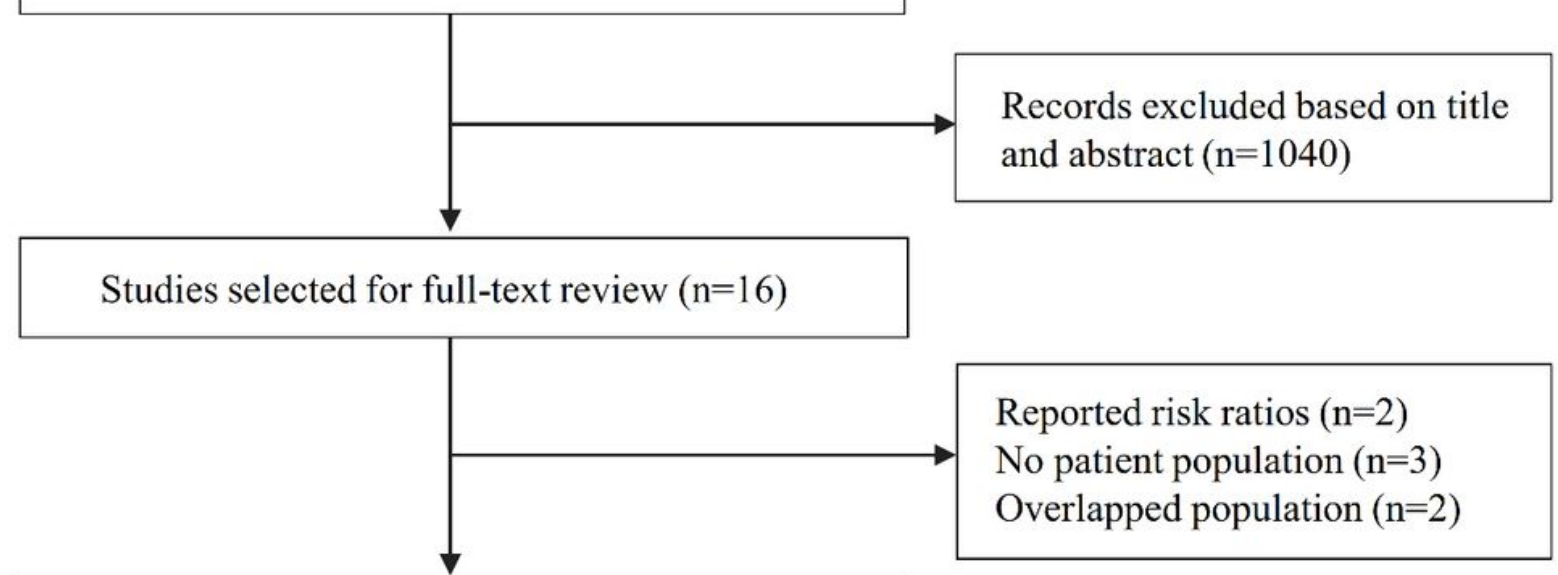

Studies included in systematic review and metaanalysis $(n=9)$

Figure 1

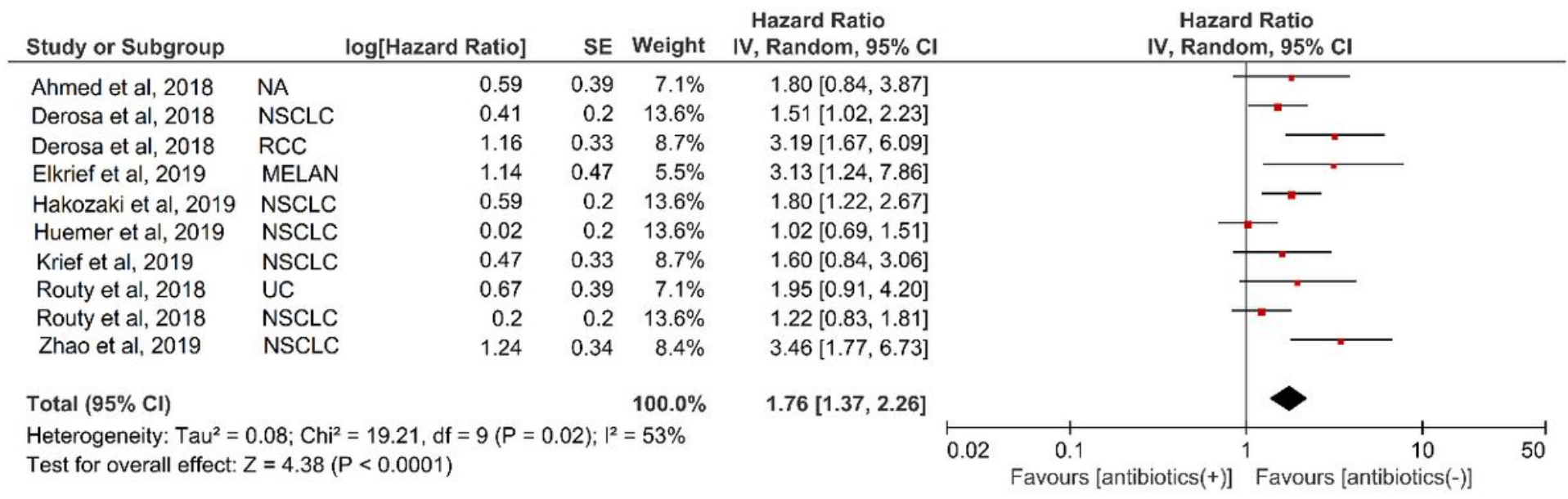


Figure 2

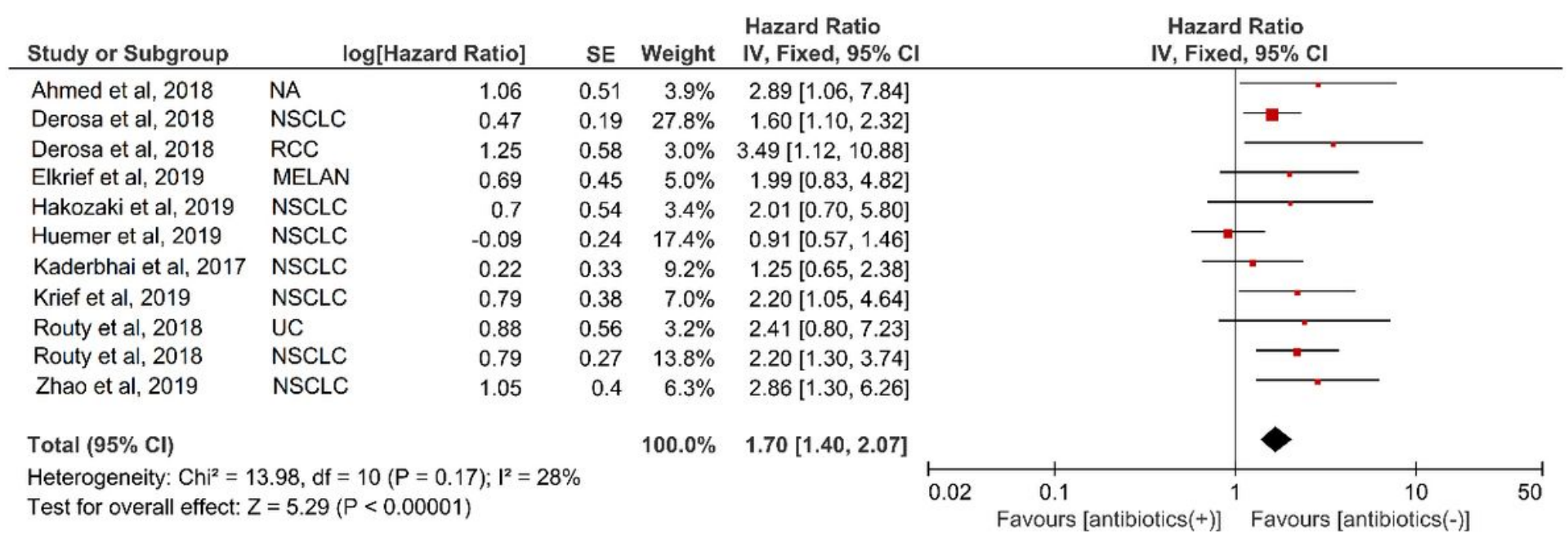

Figure 3

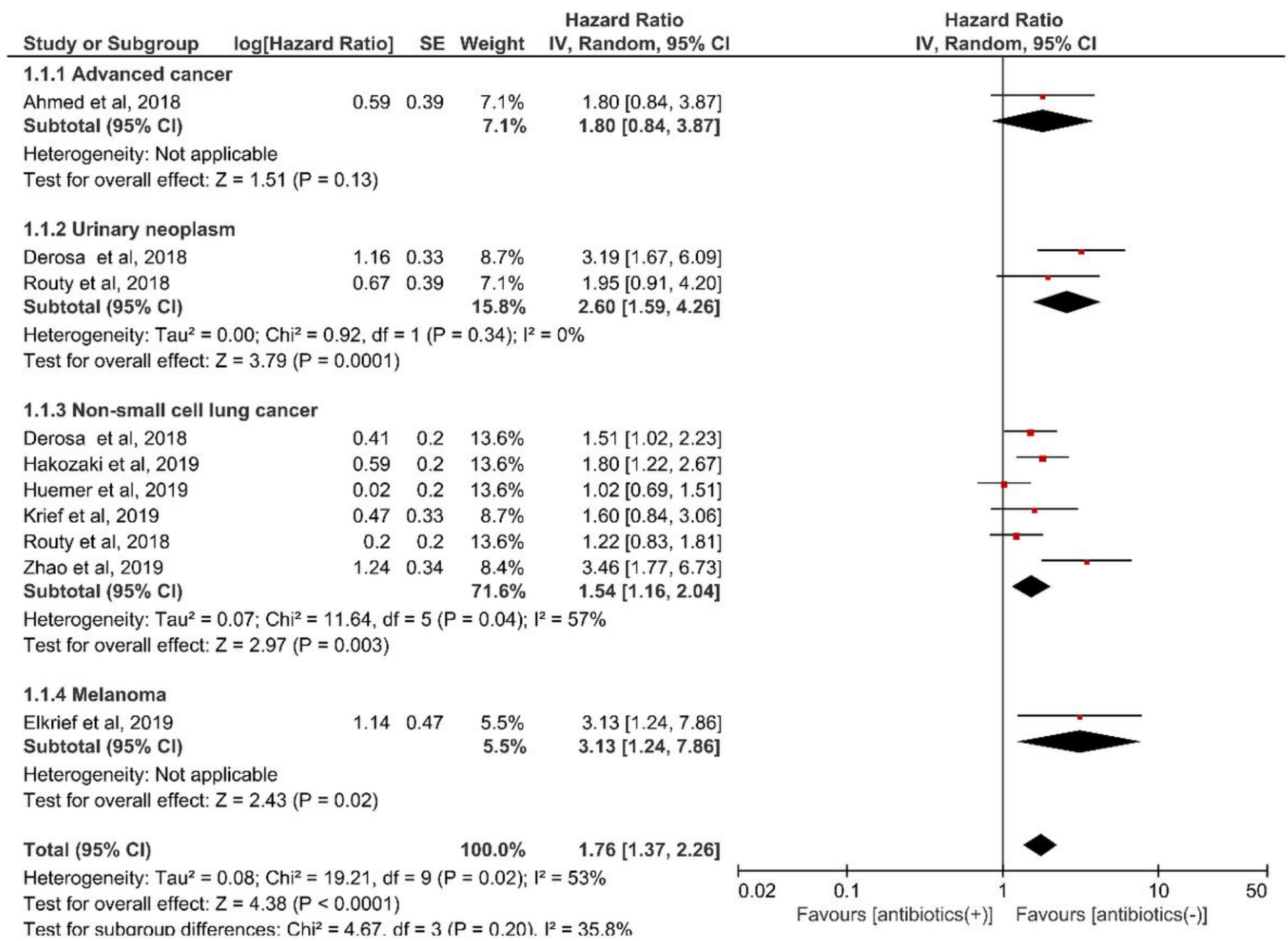

Figure 4 
Hazard Ratio

Study or Subgroup log[Hazard Ratio] SE Weight $\quad$ IV, Random, 95\% Cl

1.2.1 Non-multivariate analysis

Ahmed et al, 2018

Derosa et al, 2018

Hakozaki et al, 2019

Huemer et al, 2019

Routy et al, 2018

Subtotal $(95 \% \mathrm{Cl})$

Heterogeneity: $\mathrm{Tau}^{2}=0.01 ; \mathrm{Chi}^{2}=5.11, \mathrm{df}=4(\mathrm{P}=0.28) ; \mathrm{I}^{2}=22 \%$

Test for overall effect: $Z=2.93(P=0.003)$

\subsubsection{Multivariate analysis}

Derosa et al, 2018

Elkrief et al, 2019

Krief et al, 2019

Routy et al, 2018

Zhao et al, 2019

Subtotal $(95 \% \mathrm{Cl})$

Heterogeneity: Tau

Test for overall effect: $Z=5.71(P<0.00001)$

Total $(95 \% \mathrm{CI})$

$\begin{array}{rrr}1.16 & 0.33 & 8.7 \% \\ 1.14 & 0.47 & 5.5 \% \\ 0.47 & 0.33 & 8.7 \% \\ 0.67 & 0.39 & 7.1 \% \\ 1.24 & 0.34 & 8.4 \% \\ & & 38.4 \%\end{array}$

$3.19[1.67,6.09]$

$3.13[1.24,7.86]$

$1.60[0.84,3.06]$

$1.95[0.91,4.20]$

$3.46[1.77,6.73]$

$2.52[1.84,3.46]$

$0.42) ; 1^{2}=0 \%$

Heterogeneity: $\mathrm{Tau}^{2}=0.08 ; \mathrm{Chi}^{2}=19.21, \mathrm{df}=9(\mathrm{P}=0.02) ; \mathrm{I}^{2}=53 \%$

Test for overall effect: $Z=4.38(P<0.0001)$

Test for subaroun differences: $\mathrm{Chi}^{2}=9.29 . \mathrm{df}=1(\mathrm{P}=0.002) . \mathrm{I}^{2}=89.2 \%$
Hazard Ratio

IV, Random, $95 \% \mathrm{Cl}$

\section{Figure 5}

(A)

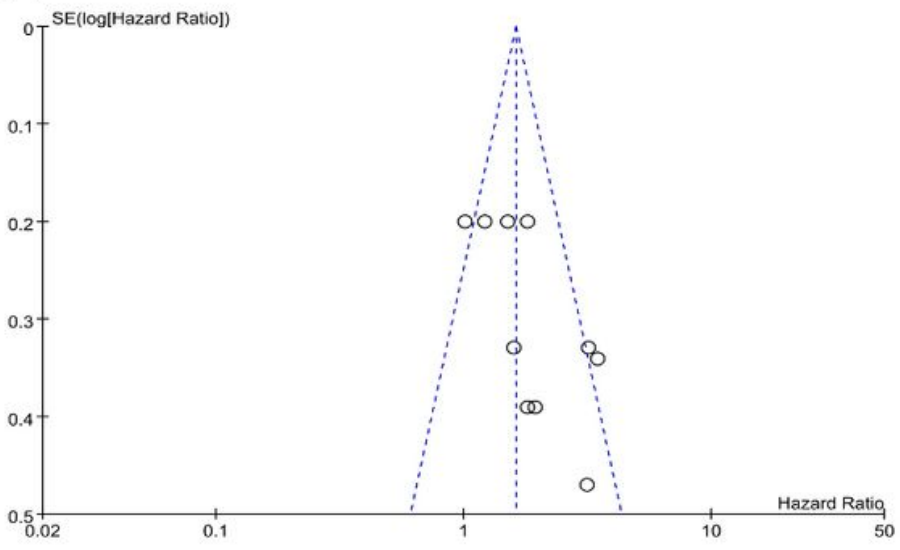

(B)

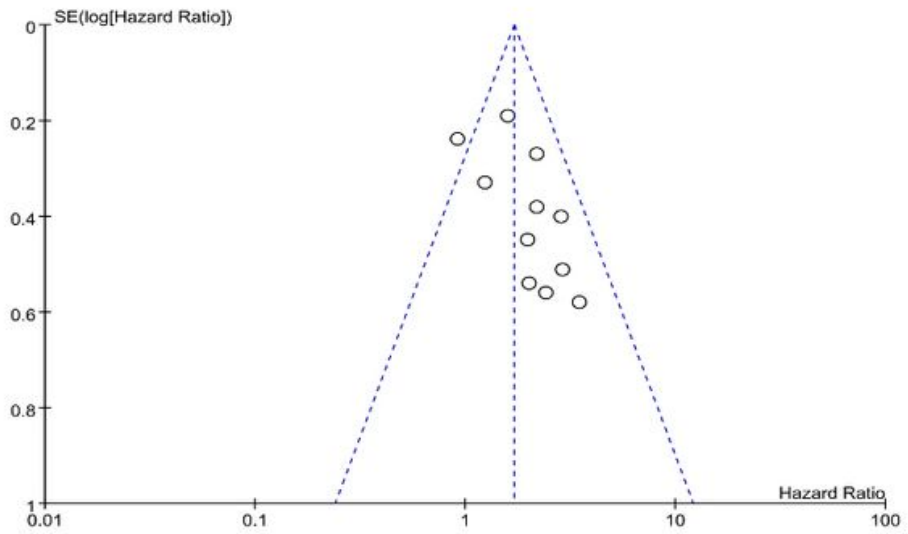

Figure 6 
(A) Meta-analysis estimates, given named study is omitted

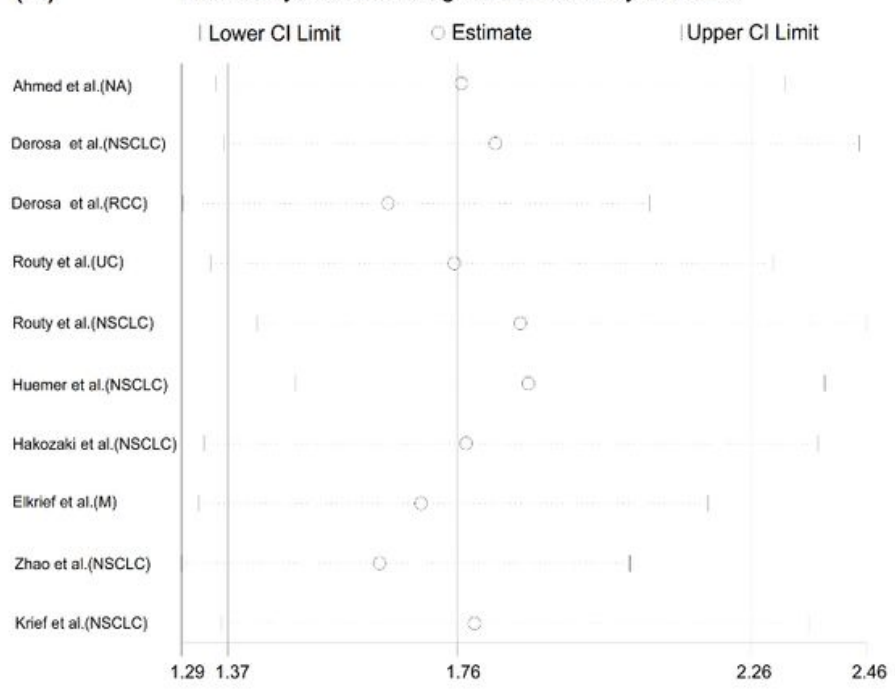

(B) Meta-analysis estimates, given named study is omitted

Ahmed et al.(NA)

Derosa et al.(NSCLC

Derosa et al.(RCC)

Routy et al.(UC)

Routy et al.(NSCLC)

Huemer et al.(NSCLC)

Kaderbhai et al.(NSCLC)

Hakozaki et al.(NSCLC)

Elkrief et al.(M)

Zhao et al.(NSCLC)

Krief et al.(NSCLC) Upper Cl Limit

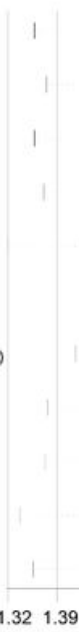

Estimate

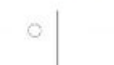

$1.32 \quad 1.39$

2.29

\section{Figure 7}

